\title{
EVALUASI PENYELENGGARAAN \\ PROGRAM WAJIB BELAJAR PENDIDIKAN DASAR PADA PONDOK PESANTREN SALAFIYAH
}

\section{EVALUATION OF IMPLEMENTATION OF MANDATORY BASIC EDUCATION PROGRAM AT PONDOK PESANTREN SALAFIYAH}

\author{
Iyoh Mastiyah \\ Puslitbang Pendidikan Agama dan Keagamaan \\ Jl. MH Thamrin No. 6 Jakarta Pusat \\ Email: imastris@yahoo.co.id
}

Naskah diterima 25 Desember 2015, direvisi 10 Januari 2016, disetujui 25 Maret 2016

\begin{abstract}
This study describes the degree of adherence to compulsory education program (compulsory basic education) at Pondok Pesantren Salafi (PPS). This study was conducted in 2015 in four Provinces namely Jakarta, Central Java, East Java and Yogyakarta using evaluation approach. The results of data analysis showed that the Compulsory Basic Education program is seen from the dimensions of the context of having high readiness with a degree of fulfillment / suitability above $80 \%$ with regard to both Ula and Wustha, Likewise, the dimension of the product is quite successfully shown an increase in value and the uptake of education, in which there are many students graduating from Ula and Wustha continue to pursue higher education and in terms of average scores, scores of Indonesian, mathematics and science increased in the academic year 2014 compared to the previous academic year. However, input dimensions and process only reached the level of "sufficiently fulfilled".
\end{abstract}

Keywords: Evaluation, Program, Compulsory Basic Education, Pesantren Salafiyah
Abstrak

Penelitian ini menjelaskan tingkat keterlaksanaan program wajib belajar pendidikan dasar (Wajar Dikdas) pada Ponpes Salafiyah (PPS). Studi ini dilakukan tahun 2015 di empat Propinsi yaitu DKI Jakarta, Jawa Tengah, Jawa Timur dan Yogyakarta dengan menggunakan pendekatan Evaluasi. Hasil analisis data menunjukan bahwa program wajar dikdas dilihat dari dimensi konteks mempunyai kesiapan yang tinggi dengan tingkat keterpenuhan/kesesuaian diatas $80 \%$ baik Ula maupun Wustha, Demikian juga dimensi produk cukup berhasil yang ditunjukan adanya peningkatan nilai dan serapan pendidikan, dimana santri lulusan Ula dan Wustha banyak yang melanjutkan ke jenjang pendidikan yang lebih tinggi dan dari sisi rerata nilai Bahasa Indonesia, matematika dan IPA meningkat pada tahun ajaran 2014 dibandingkan tahun ajaran sebelumnya. Namun dari sisi dimensi input dan proses hanya mencapai tingkat cukup terpenuhi.

Kata Kunci : Evaluasi, Program, Wajar Dikdas, Pesantren Salafiyah 


\section{PENDAHULUAN}

UU Sisdiknas no 20 tahun 2003 menjelaskan bahwa setiap warga negara berhak mendapat pendidikan. Untuk memenuhi amanat UU tersebut salah satunya pemerintah telah menyediakan program wajib belajar pendidikan dasar(wajar dikdas). Program wajar dikdas adalah program pendidikan minimal yang harus diikuti oleh warga negara Indonesia atas tanggung jawab pemerintah. Program tersebut dimulai tahun 1994 yang pelaksanaannya dituangkan dalam Inpres No 1 tahun 1994.

Untuk menyukseskan program tersebut Kementerian Agama mengambil peran pelaksanaannya dengan melibatkan madrasah dan ponpes, yang melahirkan kesepakatan bersama antara Kemendiknas dan Kemenag. ${ }^{1}$ Tujuan penyelenggaraan wajar dikdas di PPS adalah untuk mengoptimalkan Pelayanan Program Nasional Wajar Dikdas melalui salah satu jalur alternative dalam hal ini ponpes dan untuk meningkatkan peran serta ponpes bagi para peserta didik (santri), sehingga para santri dapat memiliki kemampuan setara dan kesempatan yang sama untuk

1 Menteri Pendidikan Nasional dan Menteri Agama melalui surat keputusan bersama Nomor:1/U/KB/2000 tentang pedoman Pelaksanaan Ponpes Salafiyah sebagai pola wajib belajar pendidikan dasar 9 tahun. Kesepakatan tersebut ditindaklanjuti dengan Keputusan Bersama Direktur Jenderal kelembagaan Agama Islam Departemen Agama dengan Direktur Jenderal Pendidikan Dasar dan Menengah Departemen Pendidikaan Nasional Nomor; E/83/2000 dan nomor 166/C/Kep/DS/2000 tentang pedoman pelaksanaan Ponpes Salafiyah selanjutnya disebut PPS) sebagai pola wajib belajar pendidikan dasar. melanjutkan pendidikan ke tingkat yang lebih tinggi. ${ }^{2}$

Dari pelaksanaan program tersebut diharapkan target angka partisipasi khusus (APK) akhir tahun 2008 secara nasional mencapai 95\%. Namun berdasarkan laporan Diknas tahun 2010 APK telah mencapai 95,4\% dengan rincian SD/MI/sederajat, 98,1\% SMP/MTs/sederajat dan 70,3\% SMA/MA/ SMK/sederajat. Program tersebut di PPS masih berjalan hingga saat ini. Oleh karena itu, perlu dilakukan evaluasi untuk melihat sejauhmana keterlaksanaan program wajar dikdas di PPS meliputi: dimensi konteks, input, proses dan produk penyelenggaraan program?

Evaluasi ini diharapkan memiliki manfaat strategis. Secara teoritik dapat memberikan kontribusi untuk pengembangan keilmuan terkait program pendidikan dasar. Secara praktis dapat memberi saran dan masukan untuk dijadikan bahan pertimbangan bagi para pimpinan Kementerian Agama tentang langkah-langkah konkrit dan komprehensip dalam menyususn kebijakan tentang pembinaan dan pengembangan pelaksanaan program wajar dikdas pada ponpes. Selain itu memberi saran dan masukan bagi penyelenggara program wajar dikdas dalam hal ini ponpes untuk melakukan perbaikan dan peningkatan mutu penyelenggaraan program wajar dikdas.

${ }^{2}$ Direktorat Jederal Kelembagaan Agama Islam, Panduan Teknis Penyelenggaaraan pada Ponpes Salaafiyah, Tahun 2001 


\section{Kerangka Konseptual}

Wajib belajar pendidikan dasar adalah suatu gerakan nasional yang diselenggarakan di seluruh Indonesia bagi warga Negara yang berusia 7-15 tahun untuk mengikuti pendidikan dasar atau pendidikan yang setara sampai tamat, dengan biaya dibebankan pada APBN dan APBD serta sumber lain yang tidak mengikat. $^{3} \quad$ Program tersebut adalah program pendidikan minimal yang harus diikuti oleh warga negara Indonesia atas tanggung jawab Pemerintah dan Pemerintah Daerah. ${ }^{4}$ Target program ini tercapainya angka partisipasi sekolah (APS) atau angka partisipasi Kasar (APK) dan angka partisipasi Murni (APM) $95 \%$ pada akhir tahun 2008. Wajar dikdas diarahkan agar diikuti oleh semua warga Negara Indonesia yang berusia 7-15 tahun untuk sekolah dasar dan berusia 13-15 tahun untuk sekolah lanjutan Tingkat Pertama dan yang sederajat. ${ }^{5}$ Pendidikan dasar adalah pendidikan umum yang lamanya 9 tahun dengan perincian 6 tahun di sekolah dasar atau yang setara dan tiga tahun di Sekolah Menengah Pertama atau satuan yang setara.

Pondok Pesantren Salafiyah (PPS) yaitu ponpes yang masih mempertahankan sistem pendidikan khas ponpes, baik kurikulum, metode, maupun bahan ajarnya. Bahan ajar yang diberikan meliputi ilmuilmu agama Islam dengan mempergunakan kitab-kitab klasik berbahasa Arab, sesuai

\footnotetext{
${ }^{3}$ Inpres No 1 Tahun 1994,15 April 1994 tentang Pelaksanaan Wajib Belajar Pendidikan Dasar

${ }^{4}$ Undang-Undang Nomor 20 tahun 2003 tentang sistem pendidikan Nasional

${ }^{5}$ Inpres No 1 Tahun 1994,15 April 1994 tentang Pelaksanaan Wajib Belajar Pendidikan Dasar
}

dengan tingkat kemampuan masing-masing santri, dan proses pembelajaran masih mempertahankan metode bandongan dan sorogan. ${ }^{6}$ Program wajib belajar pada PPS ini khusus untuk santri yang belum mendapatkan pendidikan dasar.

Adapun evaluasi adalah sebagai proses pencarian, pengumpUlan dan pengambilan data (informasi) yang diperlukan untuk memberikan pertimbangan apakah program yang sedang berjalan perlu diperbaiki, dihentikan atau diteruskan. ${ }^{7}$ Evaluasi program dilakukan secara sistematis, rinci, dan menggunakan prosedur yang sudah diuji secara cermat dengan metode tertentu akan diperoleh data yang dapat dipercaya. Evaluasi dapat digunakan untu penentu kebijakan. Kebijakan akan tepat apabila data yang digunakan sebagai pertimbangan tersebut benar, akurat, dan lengkap, karena evaluasi dapat menentukan ketercapaian sebuah program. Seperti diungkapkan Bigman bahwa evaluasi program, yaitu: (1) Untuk menemukan apakah tujuan dapat dicapai, dan seberapa jauh dapat dicapai. (2) Untuk menemukan prinsip yang melandasi keberhasilan program. (3) Untuk melakukan eksperimen-eksperimen dengan teknik-teknik tertentu guna meningkatkan efektifitas. (4) Untuk meletakkan dasar guna melakukan penelitian lanjut atas dasar keberhasilan alternative teknik yang digunakan. (5) Untuk merumuskan kembali cara yang akan digunakan dalam mencapai

\footnotetext{
6 Panduan Teknis Penyelenggaraan Program Wajib Belajar Pendidikan Dasar Pada Ponpes Salafiyah.Direktorat Jenderal Kelembagaan Agama Islam Kementerian Agama, 2001

7 W. James Popham, 1981. Modern Educational Evaluation, New Jersey: Prenctice Hall Inc, h. 7.
} 
tujuan, dan bahkan merumuskan kembali sub tujuan sesuai dengan temuan penelitian. ${ }^{8}$

\section{METODOLOGI PENELITIAN}

Pendekatan yang digunakan dalam penelitian ini kuantitatif dengan menggunakan penelitian evaluasi model CIPP Stufflebeam dan kawan-kawan. Dalam model CIPP terdapat empat dimensi yaitu contexs, input, process, dan product. Contexs adalah sesuatu hal yang melatarbelakangi adanya penyelenggaraan program wajar dikdas di PPS dan berkaitan dengan lingkungan program yang mencakup kebutuhan masyarakat dan kelayakan PPS penyelenggara. Input adalah prsoalan yang berhubungan dengan penggunaan sumbersumber yang tersedia yang dihubungkan dengan pendidik, kurikulum, sarana prasarana dan kelengkapan administrasi. Proses adalah berkaitan dengan bagaimana mengimplementasikan keputusan dalam kegiatan atau mengidentifikasi permasalahan prosedur implementasi baik tata kelola maupun aktivitas proses pembelajaran serta masalah dan kendala yang dihadapi. Product adalah berkaitan dengan keberhasilan pencapaian tujuan yang telah ditetapkan yang mencakup hasil ujian, serapan pendidikan lanjutan dan manfaat penyelenggaraan

Populasi penelitian adalah ponpes penyelenggara wajar dikdas di empat propvinsi yaitu DKI Jakarta, Jawa Tengah, Jawa Timur dan Yogyakarta, yang dilaksanakan pada bulan April sampai dengan bulan september 2015. Sedangkan

8 Leonard Rutman. 1984. Evaluation Research Methodology, New Delhi: Sege Publication India PVT. Ltd, 2 ed, h. 123 prosedur pengambilan sampel ditentukan secara proporsional perkabupaten/kota. Tahap selanjutnya memilih 10 Kabupaten/ Kota dengan popUlasi terbanyak PPS penyelenggara program Ula dan Wustha. Dari data 10 terbanyak penyelenggara program tersebut ditemukan sebanyak 132 sampel program Ula dan 179 program Wustha dengan margin error 10 dan tingkat kepercayaan 95\%.

Untuk menentukan PPS penyelenggara yang dijadikan sasaran penelitian di masingmasing kabupaten/kota ditentukan secara purposive yaitu dengan cara memilih sampel berdasakan kriteria tertentu yakni ponpes penyelenggara wajar dikdas tersebut telah berdiri minimal 3 tahun dan jumlah santri minimal 15 orang sesuai dengan ketentuan penyelenggaraan wajar dikdas. Adapun tehnik pengumpulan data dilakukan dengan pengisian kuesioner dalam bentuk angket/pilihan, dimana masing-masing penanggungjawab program diminta mengisi atau memilih jawaban yang telah disediakan dalam bentuk pilihan a,b,c,d atau e dan steterusnya. Selanjutnya data hasil penelitian dianalisis dengan menggunakan tehnik analisis statistik deskriptif.

\section{HASIL DAN PEMBAHASAN}

Dari data yang terkumpul sampel yang terjaring dan dapat diolah sebanyak 123 (21 kabupaten/kota) sampel Ula dan 171 Wustha (24 kabupaten/kota). Selanjutnya data dianalisis menggunakan statistik deskriptif, yaitumenguraikan distribusi responjawaban dari setiap ponpes terhadap indikator yang mengukur tingkat keterlaksanaan program wajar dikdas dilihat dari empat dimensi 
yaitu dimensi konteks, input, proses serta produk.

Untuk pemaknaan data kuantitatif dalam penelitian ini menggunakan jenis data kategoris yang pemaknaannya yaitu efektif, terpenuhi, terlaksana dan sejenisnya. Sedangkan data yang dihitung untuk tingkat kesesuaian/ keterpenuhan tersebut berdasarkan jumlah sampel yang menjawab, dengan skala yang dipakai yaitu:

85 - 100\% (Sangat terpenuhi)

$\sim 71$ - 84\% (terpenuhi)

$\sim 56$ - 70\% (Cukup terpenuhi)

$\sim 40$ - 55\% (kurang terpenuhi)

0 - 39\% (Sangat Kurang terpenuhi)

\section{Profil Kelembagaan Pondok Pesantren}

Deskripsi profil ponpes penyelenggara Program Wajar Dikdas ini dilihat dari lima aspek yaitu aspek tahun berdiri, latar belakang pendidikan Kyai/Pengasuh, jumlah santri mukim dan non mukim, jumlah ustadz/ah serta rasio antara jumlah ustadz/ah dengan jumlah santri. Kelima aspek tersebut dihitung berdasarkan jumlah data sampel yang menjawab.

Dihitung dari sampel yang menjawab dengan proporsi total 100\%, ada kecenderungan bahwa Ula maupun Wustha menunjukan relatif trend sama. Pertama ponpes berdiri sebelum tahun 1980 ada 18\% Ula dan 29\% Wustha. Kemudian terjadi peningkatan jumlah (proporsi) ponpes yang cukup signifikan antara tahun 1980 menuju tahun 2010 dimana tercatat ada 39.8\% Ula dan $29.9 \%$ Wustha yang paling mendominai proporsi sampel penelitian. Setelah tahun 2010 nampaknya jumlah sampel dalam penelitian ini menunjukan proporsi paling rendah.

Selanjutnya tahun berdiri berdasarkan sampel menunjukan bahwa ponpes mulai ikut program wajar dikdas cukup beragam, ada ponpes yang sudah melaksanakan wajar dikdas jauh sebelum adanya regulasi, padahal menurut buku petunjuk teknis penyelenggaraan program wajar dikdas yang diterbitkan Kementerian Agama, program wajar dikdas baru ditetapkan tahun 2000 melalui kesepakatan bersama antara Menteri Agama RI dengan Menteri Pendidikan Nasional dengan surat keputusan bersama Nomor :1/U/KB/2000. Namun hasil pengamatan dari data, nampaknya ada $5 \%$ Ula dan $4 \%$ Wustha telah menyelenggarakan program wajar dikdas sebelum tahun 2000 , sedangkan sisanya 94.7\% Ula dan 96.\% Wustha program berjalan setelah regUlasi keluar tahun 2000. Distribusi dimUlainya penyelenggaraan program ini paling dominan baik Ula maupun Wustha antara tahun 2006 hingga 2010.

Terkait keberadaan pendidikan kyai/ pengasuh dari sampel yang menjawab menunjukan bahwa Kyai/Pengasuh ponpes menempuh pendidikan hingga perguruan tinggi (pendidikan formal) minimal sarjana baik sampel data Ula maupun Wustha menunjukan trend hampir sama yaitu $27 \%$ Ula dan 29\% Wustha. Sedangkan yang berpendidikan SMA/MA/SMK/Sederajat cukup mendominasi dalam penelitian ini baik sampel Ula maupun Wustha. Kyai/ Pengasuh pondok yang hanya berlatar belakang pendidikan ponpes kurang dari 10\%. Sedangkan Jumlah Ustadz/ah dari 117 Ula dan 164 Wustha umumnya kurang dari 20 orang. Proporsi ponpes dengan tenaga pengajar kurang dari 10 cukup signifikan 
yaitu 37\% Ula dan 34\% Wustha, kemudian diikuti oleh jumlah ustadz/ah dengan jumlah guru 11-20 orang yaitu mencapai 49\% (Ula) dan 31\% (Wustha).

Jumlah santri dalam suatu ponpes yang menyelenggarakan pendidikan Ula kurang dari 50 santri terdapat 16\% dan $21 \%$ Wustha. Santri dengan jumlah cukup besar lebih dari 250 santri juga cukup banyak dalam penelitian ini yaitu $22 \%$ Ula dan $27 \%$ Wustha, sedangkan berdasarkan klasifikasi mukim dan non mukim dengan melihat total santri ponpes dari sampel yang menjawab 68 Ula dan 118 Wustha tercatat jumlah santri yang "mukim" baik Ula (55.3\%) maunpun Wustha (69.9\%) lebih banyak dari santri yang "tidak mukin (non mukim)".

Rasio Ustadz/ah atau tenaga pengajar berguna untuk melihat kelayakan pembelajaran. Menurut standar Nasional Pendidikan "rasio ideal dalam proses pembelajaran adalah jumlah maksimal peserta didik setiap rombongan belajar adalah SD/MI 28 peserta didik dan tingkat SMP/MTS 32 peserta didik ${ }^{9}$ Sementara hasil penelitian menunjukan rasio tenaga pengajar dengan santri 1:20 ada 35\% Ula dan $36 \%$ Wustha. Ini artinya proses pembelajaran di ponpes tergolong efektif, dimana rasio antara guru dengan santri antara 1:10 dan 1:20. Dengan demikian dilihat dari profil ponpes tersebut maka penyelenggara wajar dikdasyang menjadi sampel dalam penelitian

\footnotetext{
9 Lihat Pesaturan Menteri Pendidikan Nasional Republik Indonesia, No 41 tahun 2007 tentang standar Proses untuk Satuan Pendidikan Dasar dan Menengah. Jumlah rombongan belajaraPersyaratan Pelaksanaan Proses Pembelajaran. Jumlah maksimal peserta didik setiap rombongan belajar adalah: SD/MI : 28 peserta didik, SMP/ MT : 32 peserta didik, SMA/MA : 32 peserta didik dan SMK/MAK : 32 peserta didik
}

ini cukup proporsional atau cukup mewakili dari berbagai karakter ponpes.

\section{Penyelenggaraan Program Wajar Dikdas}

Hasil analisis data penyelenggaraan program wajar dikdas dilihat dari empat dimensi yaitu konteks, input, proses dan produk dapat dijabarkan berikut:

\section{Aspek Konteks}

Konteks adalah sesuatu yang melatarbelakangi penyelenggaraan program wajar dikdas di PPS yang berkaitan dengan lingkungan program, mencakup kebutuhan masyarakat dan kelayakan ponpes penyelenggara. Dalam hal ini ada lima indikator yang digunakan untuk melihat kesesuaian atau keterpenuhan penyelenggaraan program wajar dikdas 'Ula dan Wustha. yaitu;

Tabel 1: Indikator Dimensi Konteks

\begin{tabular}{|c|l|l|}
\hline No & \multicolumn{1}{|c|}{ Indikator } & \multicolumn{1}{c|}{ Skala Pengukuran } \\
\hline 1 & $\begin{array}{l}\text { Rumusan visi misi ponpes } \\
\text { mengandung program wajar } \\
\text { dikdas }\end{array}$ & $1=$ ya, $0=$ tidak \\
\hline 2 & $\begin{array}{l}\text { Ponpesmempunyai } \\
\text { buku Petunjuk Teknis } \\
\text { Penyelenggaraan Program } \\
\text { Wajari Dikdas pada PPS }\end{array}$ & $1=$ ya, $0=$ tidak \\
\hline 3 & $\begin{array}{l}\text { Keikutsertaan ponpes dalam } \\
\text { sosialisasi Buku Petunjuk Teknis } \\
\text { Penyelenggaraan Program } \\
\text { Wajar Dikdas pada PPS }\end{array}$ & $1=$ ya, $0=$ tidak \\
\hline 4 & $\begin{array}{l}\text { Kepahaman ponpes terhadap } \\
\text { prosedur Program Wajar Dikdas } \\
\text { pada PPS yang tertulis di dalam } \\
\text { buku petunjuk teknis tersebut } ?\end{array}$ & $\begin{array}{l}0=\text { tidak memahami, } \\
2=\text { memaham memahami, }\end{array}$ \\
\hline 5 & $\begin{array}{l}\text { Kemandirian ponpesdalam } \\
\text { membuat panduan pelaksanaan } \\
\text { wajar dikdas yang digunakan di } \\
\text { internal ponpes }\end{array}$ & $1=$ ya, $0=$ tidak \\
\hline
\end{tabular}

Rumusan visi dan misi ponpes yang menyertakan program wajar dikdas sangat penting. Karena visi berkaitan dengan tujuan akhir yang ingin dituju. Sedangkan 
misi berkaitan dengan program-program yang akan dilakukan oleh ponpes dalam rangka mencapai visi. Ponpes yang menyertakan program wajar dikdas dalam visi dan misi ponpes dapat diduga bahwa ponpes mengalami pembaruan dan perubahan, dengan tetap menjunjung tinggi konsep tafaquh fiddin sebagai tujuan akhir berdirinya ponpes.

Hasil analisis tercatat bahwa sebagian besar menyatakan sudah memasukan program penyelenggaraan wajar dikdas dalam visi dan misi ponpes 95\% Ula dan 96\% Wustha. Ini memberikan indikasi bahwa ponpes sekarang mengalami transformasi pembaharuan untuk mendukung program pemerintah dalam menyiapkan sumber daya manusia untuk mensukseskan pembangunan dalam bidang pembangunan manusia.

Penanggung jawab program ini ternyata tidak selamanya berada di tangan Kyai/ Pengasuh ponpes, dimana hasil jawaban responden adalah penanggungjawab program lebih dominan Ustadz senior yang mempunyain proporsi lebih tinggi $62 \%$ Ula dan 61\% Wustha. Penaggung jawab program sangat penting dalam program penyelenggaraan wajar dikdas sebagai orang yang sepenuhnya bertanggung jawab terhadap keberhasilan pelaksanaan program melalui kegiatan supervisi dan monitoring.

Selain adanya penaggung jawab program, ketersediaan buku petunjuk teknis pelaksanaan program juga penting. Buku teknis berguna sebagai petunjuk teknis atau dasar panduan bagaimana program wajar dikdas tersebut dijalankan. Berdasarkan pengolahan sampel yang menjawab diketahui 95\% Ula dan 97\% Wustha ponpes menyatakan bahwa mereka mempunyai buku petunjuk teknis. Mereka yang tidak mempunyai buku petunjuk teknis umumnya membuat panduan sendiri.

Untuk memperoleh informasi yang seutuhnya tentang program penyelenggaraan wajar dikdas maka setiap penanggung jawab program atau pengasuh ponpes perlu mengikuti sosialisasi program. Data menunjukan bahwa keikutsertaan sosialisasi tercatat 93\% Ula dan 96\% Wustha. Sedangkan ponpes yang menyatakan tidak mengikuti sosialisasi lebih karena alasan mengetahaui tapi tidak sempat. Tingginya apresiasi ponpes mengikuti sosialisasi program wajar dikdas menunjukan bahwa mereka memiliki minat dan keseriusan tinggi dalam mendukung program ini. Sumber informasi program sosialisasi ini umumnya berasal dari pihak Kemenag Kabupaten/Kota, Kemenag Kanwil dan Dinas Pendidikan.

Tingkat Kepahaman atas prosedur program wajar dikdas yang tertulis dalam buku petunjuk teknis, menunjukan ada 75\% Ula dan $81 \%$ Wustha, memahami akan isi buku petunjuk teknis penyelenggaraan program. Meskipun demikian mereka yang kurang atau tidak memahami umumnya langsung meminta penjelasan ke Kemenag Kabupaten/Kota atau ponpes lainnya atau ke Dinas Pendidikan.

Selain ponpes memiliki buku petunjuk teknis, juga diharapkan untuk membuat panduan mandiri disesuaikan dengan kurikulum ponpes. Panduan mandiri ini diharapkan dapat menerjemahkan dan menurunkan petunjuk praktis yang disesuaikan dengan lingkungan pembelajaran ponpes. Selain itu tujuan 
panduan mandiri lebih menekankan aspek kemudahan dalam penyelenggaraan program serta evaluasi program. Hasil penelitian, tercatat Ula ada $64 \%$, lebih tinggi dari Wustha 53\%. Ponpes yang membuat panduan mandiri menyatakan bahwa pembuatan panduan tersebut melibatkan tenaga pengajar di ponpes beserta Kyai/ Pengasuh. Dari beberapa indikator yang telah ditetapkan untuk mengukur dimensi konteks, maka dapat dihitung keterpenuhan / kesesuaiannya sebagai berikut.

Tabel 2 : Kesesuaian/keterpenuhan dimensi konteks

\begin{tabular}{|c|l|c|c|c|}
\hline \multirow{2}{*}{ No } & \multicolumn{1}{|c|}{ Indikator } & \multirow{2}{*}{$\begin{array}{c}\text { Kriteria } \\
\text { Jawaban }\end{array}$} & \multicolumn{2}{|c|}{ Efektifitas } \\
\cline { 3 - 5 } & & Ula & Wustha \\
\hline 1 & $\begin{array}{l}\text { Rumusan visi misi } \\
\text { ponpesmengandung program } \\
\text { wajar dikdas }\end{array}$ & $95 \%$ & $96 \%$ \\
\hline 2 & $\begin{array}{l}\text { Ponpesmempunyai } \\
\text { buku Petunjuk Teknis } \\
\text { Penyelenggaraan }\end{array}$ & Ya & $95 \%$ & $97 \%$ \\
\hline 3 & $\begin{array}{l}\text { Keikutsertaan dalam sosialisasi } \\
\text { Buku Petunjuk Teknis } \\
\text { Penyelenggaraan Program } \\
\text { Wajar Dikdas pada PPS }\end{array}$ & Ya & $93 \%$ & $96 \%$ \\
\hline 4 & $\begin{array}{l}\text { Kepahaman prosedur Program } \\
\text { Wajar Dikdas yang tertulis } \\
\text { dalam buku petunjuk teknis }\end{array}$ & Paham & $75 \%$ & $81 \%$ \\
\hline 5 & $\begin{array}{l}\text { Kemandirian membuat } \\
\text { panduan pelaksanaan wajar } \\
\text { dikdas internal ponpes }\end{array}$ & Ya & $64 \%$ & $53 \%$ \\
\hline & \begin{tabular}{l} 
Kesesuaian/Keterpenuhan Dimensi Konteks \\
\hline
\end{tabular} & $84.4 \%$ & $84.6 \%$ \\
\hline
\end{tabular}

Secara keseluruhan kesesuaian atau keterpenuhan dimensi konteks berada pada tingkat "sesuai/terpenuhi" baik Ula $84.4 \%$ maupun Wustha 84.6\%. Ini memberikan indikasi bahwa latar belakang yang mendorong pelaksanaan program sangat baik dipahami dan dilaksanakan oleh ponpes dalam menyelenggarakan program wajar dikdas. Kontribusi terbesar adalah dukungan visi misi yang secara langsung menyertakan program wajar dikdas, memiliki buku petunjuk teknis, keikut sertaan dalam kegiatan sosialisasi. Sedangkan indikator yang masih perlu diperhatikan baik program wajar dikdas Ula maupun Wustha adalah "kemandirian dalam membuat panduan untuk keperluan internal”.

\section{Aspek Input}

Input adalah sesutu yang berhubungan dengan penggunaan sumber-sumber yang tersedia, mencakup tenaga pendidik, kurikulum, ketersedian buku pembelajaran, sarana prasarana dan kelengkapan administrasi. Dalam hal ini ada 11 indikator kunci yang digunakan untuk menilai dimensi ini yaitu:

Tabel 3 : Indikator dimensi input

\begin{tabular}{|c|c|c|}
\hline No & Indikator & Skala Pengukuran \\
\hline 1 & Keberadaan pendidik (guru) & $\begin{array}{l}0=\text { Luar Ponpes, } \\
1=\text { Dalam Ponpes }\end{array}$ \\
\hline 2 & Latar belakang pendidikan guru & $\begin{array}{l}0=\text { SMA } / M A / \text { ponpes, } \\
1=\text { Diploma } / \text { Sarjana }\end{array}$ \\
\hline 3 & $\begin{array}{l}\text { Kurikulum mata pelajaran umum } \\
\text { yang digunakan }\end{array}$ & $\begin{array}{l}0=\text { tidak mengikuti } \\
\text { seluruhnya, } \\
1 \text { = mengikuti sebagian, } \\
2 \text { = mengikuti seluruhnya }\end{array}$ \\
\hline 4 & $\begin{array}{l}\text { Mapel umum yang wajib diajarkan } \\
\text { program wajar dikdas }\end{array}$ & $\begin{array}{l}1=\operatorname{ada} 1,2=\operatorname{ada} 2, \\
3=\operatorname{ada} 3\end{array}$ \\
\hline 5 & $\begin{array}{l}\text { Ketersediaan buku-buku mata } \\
\text { pelajaran umum untuk pegangan } \\
\text { santri }\end{array}$ & $\begin{array}{l}0=\text { tidak tersedia, } 1= \\
\text { sebagian tersedia, } \\
2=\text { tersedia }\end{array}$ \\
\hline 6 & $\begin{array}{l}\text { Ketersediaan buku-buku mata } \\
\text { pelajaran umum pegangan guru }\end{array}$ & $\begin{array}{l}0=\text { tidak tersedia, } 1= \\
\text { sebagian tersedia, } \\
2=\text { tersedia }\end{array}$ \\
\hline 7 & $\begin{array}{l}\text { Ketersediaan perpustakaan } \\
\text { sebagai sarana wajar dikdas }\end{array}$ & $1=$ ya, $0=$ tidak \\
\hline 8 & $\begin{array}{l}\text { Kepemilikan ponpesakan buku } \\
\text { Standar Kelulusan (SKL) }\end{array}$ & $1=$ ya, $0=$ tidak \\
\hline 9 & $\begin{array}{l}\text { kepemilikan ponpesakan } \\
\text { dokumen silabus }\end{array}$ & $1=$ ya, $0=$ tidak \\
\hline 10 & $\begin{array}{l}\text { kepemilikan akan dokumen } \\
\text { Rancangan Persiapan } \\
\text { Pembelajaran }\end{array}$ & $1=$ ya, $0=$ tidak \\
\hline 11 & $\begin{array}{l}\text { Kepemilikan jadwal pelajaran } \\
\text { untuk pelaksanaan wajar dikdas }\end{array}$ & $1=$ ya, $0=$ tidak \\
\hline
\end{tabular}

Faktor yang sangat penting dalam dimensi input adalah keberadaan guru pelajaran wajib untuk program wajar dikdas seperti Bahasa Indonesia, IPA dan 
matematika. Keberadaan guru menjadi penting untuk menunjang berhasil program. Dalam buku petunjuk teknis disebutkan bahwa ketiga mata pelajaran tersebut wajib diajarkan di jenjang Ula dan Wustha bagi ponpes yang mengikuti program wajar dikdas. Tenaga pengajar tersebut dapat berasal dari ponpes selama mempunyai kesanggupan memberikan ketiga mata pelajaran tersebut.

Hasil analisis data bahwa kelengkapan guru yang dimiliki ponpes penyelenggara yaitu asal guru mata pelajaran Umum dari yang menjawab menunjukan ada 70\% Ula dan 71\% Wusthayang secara khusus menyatakan bahwa mata pelajaran wajib diajarkan oleh guru berasal dari ponpes sedangkan 30\% Ula dan $28.6 \%$ Wustha memperoleh guru berasal dari luar ponpes. Hal lain yang menjadi nilai positif dari keberadaan guru adalah latar belakang pendididkan. Dengan meningkatnya pendidikan guru maka ada indikasi keberhasilan program wajar dikdas ini.

Selanjutnya dari sampel penelitiaan bahwa guru yang berpendidikan tinggi (menempuh kuliah) menunjukan Ula 57\% dan Wustha 67\%. Hal ini memenuhi ketentuan, karena dalam pedoman tenaga pendidik dapat memanfaatkan potensi yang ada di ponpes. Namun sesuai UU guru dan dosen untuk meningkatkan kualitas, pemerintah harus mendorong guru untuk menempuh pendidikan tinggi melalui beasiswa. Dilihat dari faktor usia tenaga pendidik pada wajar dikdas dominan usia rentang 26-45 tahun yaitu mencapai 60\% Ula dan $71 \%$ Wustha dengan komposisi tenaga pengajar lebih dominan laki-laki mencapai $67 \%$ Ula dan $65 \%$ Wustha.
Selanjutnya sampel ponpes penyelenggara program wajar dikdas yang menyatakan mengikuti seluruh kurikulum program wajar dikdas penyelenggaran Wustha lebih tinggi yaitu 54\% dibanding Ula ada $47 \%$. Ini menjadi perhatian bagi pihak pemerintah untuk senantiasa memberikan perhatian penuh kepada ponpes Ula agar terus mensosialisasikan program wajar dikdas dengan lebih memperhatikan aspek penyerapan kurikulum sepenuhnya agar santri mempunyai kesempatan memperoleh ijazah untuk melanjutkan ke jenjang lebih tinggi.

Ponpes penyelenggara wajar dikdas yang mengajarkan 3 mata pelajaran umum wajib yaitu bahasa Indonesia, IPA dan matematika tercatat Ula ada $68 \%$ dan Wustha $71 \%$. Sedangkan ponpes yang hanya mengajarkan satu mata pelajaran saja masih cukup tinggi yaitu $15 \%$.

Keberadaan buku pegangan santri ini masih cukup dirasakan perlu. Sampel menunjukan bahwa sebagian besar ponpes belum sepenuhnya mempunyai buku paket untuk santri. Ponpes yang menyatakan buku paket santri tersedia ada 37\% Ula dan 39\% Wustha. Sedangkan ketersediaan buku pelajaran umum guru jenjang Ula maupun Wustha menunjukan proporsi yang lebih tinggi yaitu lebih dari 50\% baik Ula maupun Wustha. Kepemilikan ruang kelas sebagai tempat belajar mengajar cukup dominan.

Jumlah ponpes yang menggunakan ruang kelas sebagai tempat belajar mengajar dari data sampel tercatat 92\%. Sebaliknya yang tidak menggunakan ruang kelas terhitung ada $8 \%$ yaitu menggunakan ruang belajar rumah kyai saja (3\%), masjid saja (2\%) dan masjid dan rumah Kyai (3\%). Ponpes 
yang hanya menggunakan ruang kelas saja tempat belajar mengajar mencapai $63 \%$.

Selanjutnya berdasarkan data sampel menyatakan bahwa sumber pendanaan utama penyelenggaraan wajar dikdas adalah BOS/Kemenag mencapai lebih dari 94\% baik Ula maupun Wustha. Karena itu proses kegiatan pembelajaran wajar dikdas sangat bergantung pada aliran dana BOS. Pemerintah perlu menjamin hal tersebut agar proses pembelajaran lebih produktif dan efisien.

Faktor sarana yang perlu ada dalam buku panduan wajar dikdas adalah perpustakaan. Sarana tersebut sebagai wahana bagi santri untuk lebih memahami pelajaran di luar kelas. Dengan adanya perpustakaan santri dapat menambah pengetahuan selain pengetahuan yang diberikan di kelas. Namun Ponpes yang mempunyai perpustakaan tercatat ada 59\% Ula dan 63\% Wustha. Hasil observasi lapangan terhadap keberadaan ponpes menunjukan bahwa meskipun perpustakaan ponpes ada, akan tetapi keberadaan buku, sarana pra sarana yang menunjang perpustakaan masih jauh dari yang diharapkan. Perpustakaan sebagai jendela ilmu pengetahuan bagi santri dalam menunjang program dikdas masih perlu intervensi banyak pihak baik pemerintah maupun pihak swasta. Pihak Kementerian Agama perlu memprakarsai untuk mendorong pihak perusahaan (industri) guna mendorong kesuksesan pembangunan manusia melalui pendidikan ponpes dengan menghibahkan dana CSR (social corporate responsibility) untuk penyediaan bukubuku pelajaran atau buku penunjang serta penyediaan sarana dan pra sarana bagi ponpes. Sedangkan untuk kepemilikan buku standar kelulusan (SKL), tercatat ponpes yang mempunyai buku standard kelulusan ada $78 \%$ Ula dan $75 \%$ Wustha. Selain itu kepemilikan dokumen silabus tercatat ada 54.2\% Ula dan 54.1\% Wustha. Ini artinya masih sangat kurang mengingat silabus merupakan acuan bagi guru, dimana guru tanpa adanya silabus tidak bisa membuat rancangan persiapan pembelajaran (RPP), yang akhirnya pembelajarn tidak efektif.

Ponpes wajar dikdas yang tidak memiliki dokumen silabus pada sebagian penyelenggara, maka berimplikasi pada kepemilikan dokumen rancangan persiapan pembelajaran (RPP) juga menjadi kurang. Dari sampel data, tercatat ponpes yang mempunyai dokumen RPP $64.7 \%$ Ula dan 65.4\% Wustha, dansumber dokumentersebut diperoleh dari Kemenag Kabupaten/Kota. Sedangkan Kepemilikan jadwal pelajaran diperoleh informasi dari sampel yang menjawab tercatat ada $97 \%$ Ula dan $99 \%$ Wustha memiliki jadwal, sedangkan $3 \%$ menyatakan tidak ada jadwal dan sebagian besar jadwal pelajaran sepenuhnya disusun oleh guru.

Dengan demikian hasil analisis dimensi input tersebut dapat dapat digambarkan sebagai berikut:

Tabel 4: Keterpenuhan Dimensi Input

\begin{tabular}{|c|l|c|c|c|}
\hline \multirow{2}{*}{ No } & \multicolumn{1}{|c|}{ Indikator } & \multirow{2}{*}{$\begin{array}{c}\text { Kriteria } \\
\text { Jawaban }\end{array}$} & \multicolumn{2}{|c|}{ Efektifitas \% } \\
\cline { 4 - 5 } & & Ula & Wustha \\
\hline 1 & Keberadaan pendidik (guru) & $\begin{array}{c}\text { Dari } \\
\text { Ponpes }\end{array}$ & $70 \%$ & $71.4 \%$ \\
\hline 2 & Latar belakang pendidikan guru & D/S.1 & $56.6 \%$ & $67.2 \%$ \\
\hline 3 & $\begin{array}{l}\text { Kurikulum mata pelajaran } \\
\text { umum yang digunakan }\end{array}$ & $\begin{array}{c}\text { Ikut } \\
\text { seluruh }\end{array}$ & $46.7 \%$ & $54,3 \%$ \\
\hline 4 & $\begin{array}{l}\text { Mata pelajaran umum wajib } \\
\text { pada dikdas }\end{array}$ & 3 Mapel & $66.1 \%$ & $61,6 \%$ \\
\hline 5 & $\begin{array}{l}\text { Ketersediaan buku mapel } \\
\text { umum pegangan santri }\end{array}$ & Tersedia & $37.6 \%$ & $38,9 \%$ \\
\hline 6 & $\begin{array}{l}\text { Ketersediaan buku mapel } \\
\text { umum pegangan guru }\end{array}$ & tersedia & $42.0 \%$ & $39.3 \%$ \\
\hline
\end{tabular}




\begin{tabular}{|c|l|c|c|c|}
\hline 7 & $\begin{array}{l}\text { Ketersediaan perpustakaan } \\
\text { penunjang wajar dikdas }\end{array}$ & $Y_{a}$ & $61.3 \%$ & $55.8 \%$ \\
\hline 8 & $\begin{array}{l}\text { Kepemilikan buku Standar } \\
\text { Kelulusan wajar dikdas }\end{array}$ & $Y_{a}$ & $78.2 \%$ & $74,7 \%$ \\
\hline 9 & Kepemilikan dokumen silabus & $Y_{a}$ & $54.2 \%$ & $54,1 \%$ \\
\hline 10 & Kepemilikan dokumen RPP & $Y_{a}$ & $64.7 \%$ & $65,4 \%$ \\
\hline 11 & $\begin{array}{l}\text { Kepemilikan jadwal } \\
\text { pelaksanaan pembelajaran }\end{array}$ & $Y_{a}$ & $96.7 \%$ & $98,8 \%$ \\
\hline & Keterpenuhan Dimensi Input & $61.3 \%$ & $61.9 \%$ \\
\hline
\end{tabular}

Secara keseluruhan dimensi input penyelenggaraan berada pada tingkat "cukup terpenuhi" dengan persentase 61.3\% Ula dan 61.9\% Wustha. Indikator yang memberikan kontribusi tinggi yaitu 1). Guru mata pelajaran dikdas berasal dari pontren, (2). Kepemilikan ponpes akan jadwal pelajaran wajar dikdas serta (3). adanya kepemilikan buku standard kelulusan (SKL). Beberapa hal yang perlu diperhatikan dalam program wajar dikdas dari aspek input adalah latar belakang pendidikan guru perlu ditingkatkan, (2). Buku paket pelajaran untuk santri dan guru perlu ditambah, (3) perpustakaan perlu dilengkapi sebagai sarana penunjang proses belajar, (4). silabus dan (5). dokumen Rancangan Persiapan Pembelajaran (RPP) perlu dilengkapi.

\section{Aspek Proses}

Proses adalah sesuatu yang berkaitan dengan prosedur mengimplementasikan keputusan dalam kegiatan penyelenggaraan baik tata kelola maupun aktivitas proses pembelajaran serta masalah dan kendala penyelenggaraan program. Berikut ini terdapat 8 indikator yang digunakan untuk mengetahui efektifitas dimensi proses:

Tabel 5 : Indikator Dimensi Proses

\begin{tabular}{|c|l|c|}
\hline No & \multicolumn{1}{|c|}{ Indikator } & Skala Pengukuran \\
\hline 1 & $\begin{array}{l}\text { Adanya supervisi penyelenggaraan } \\
\text { wajar dikdas di PPS }\end{array}$ & $1=\mathrm{ya}, 0=$ tidak \\
\hline
\end{tabular}

\begin{tabular}{|c|c|c|}
\hline 2 & $\begin{array}{l}\text { Adanya monitoring dalam } \\
\text { penyelenggaraan wajar dikdas } \\
\text { di PPS }\end{array}$ & $1=$ ya, $0=$ tidak \\
\hline 3 & Kelengkapan materi monitoring & $\begin{array}{l}1=1 \text { materi, } 2=2 \text { mater } \\
3=3 \text { mater, } 4=4 \text { materi }\end{array}$ \\
\hline 4 & $\begin{array}{l}\text { Adanya laporan yang dibuat dalam } \\
\text { penyelenggara program }\end{array}$ & $\begin{array}{l}0=\text { Tidak Pernah, } 1= \\
\text { kadang-kadang, }, 2= \\
\text { selalu }\end{array}$ \\
\hline 5 & $\begin{array}{l}\text { Penyesuaian pembelajaran wajar } \\
\text { dikdas dengan pembelajaran } \\
\text { ponpes }\end{array}$ & $\begin{array}{l}0=\text { tidak disesuaikan, } \\
1 \text { = sebagian disesuaikan, } \\
2 \text { = disesuaikan } \\
\text { sepenuhnya }\end{array}$ \\
\hline 6 & $\begin{array}{l}\text { Frekuensi kegiatan penilaian } \\
\text { dilakukan dalam satu tahun }\end{array}$ & $1=2$ kali , $2=3$ kali \\
\hline 7 & $\begin{array}{l}\text { Persentase kehadiran santri di } \\
\text { kelas }\end{array}$ & $\begin{array}{l}1=\text { Kurang } 50 \% \\
2=51-75 \%, 3=76- \\
100 \%\end{array}$ \\
\hline 8 & $\begin{array}{l}\text { Frekusnsi kehadiran guru dalam } \\
\text { kegiatan pembelajaran }\end{array}$ & $\begin{array}{l}0=\text { jarang, } 1=\text { kadang- } \\
\text { kadang }, 2=\text { selalu }\end{array}$ \\
\hline
\end{tabular}

Sebelum menguraikan hasil capaian dari setiap indikator dimensi proses perlu terlebih dahulu melihat proses pendaftaran suatu ponpes yang mengikuti program ini, juga dinilai perlu dihadirkan informasinya. Ponpes terlebih dahulu perlu mengikuti ketentuan yang berlaku. Karena itu, sampel yang menyatakan telah mendaftar ke kantor Kemenag Kabupaten/Kota terkait keikutsertaan program wajar dikdas tercatat ada $87 \%$ Ula dan $90.4 \%$ Wustha. Meskipun demikian terlihat ada $60.2 \%$ Ula dan $67.1 \%$ Wustha yang diklarifkasi oleh Kemenag Kota/ Kabupaten. Sementara 40,8\% Ula dan 60,3\% Wustha tidak dilakukan klarifikasi/verivikasi tetapi ditunjuk oleh Kemenag. Padahal tanggung jawab Kemenag mengklarifikasi ponpes.

Menurut buku petunjuk teknis pelaksanaan program, yang ditunjuk menjadi supervisi adalah pimpinan ponpes, penaggung jawab program, pengawas, pejabat Kemenag dan Dinas Pendidikan. Berdasarkan sampel yang menjawab menunjukan ada 97\% Ula dan 95\% Wustha menyatakan pernah di supervisi. 
Dari jumlah tersebut menyatakan bahwa supervisi yang dilakasanakan 3 kali lebih sering dilakukan oleh pimpinan ponpes dan penaggung jawab program, sedangkan Pengawas, Pejabat Kemenag, yaitu Pejabat Kanwil melaksanakan supervisi antara 1 dan 2 kali dalam setahun. Selain supervisi, program monitoring juga menjadi perlu. Monitoring berguna untuk mengetahui sejauh mana setiap tugas/instruksi dilaksanakan dan juga untuk mengetahui tahap-tahap pencapaian target yang telah ditentukan, hambatan dan lainnya. Data menunjukan ada 99\% Ula dan 99\% Wustha pernah dimonitoring. Ini dapat dikatakan bahwa proses monitoring sepenuhnya berhasil dilakukan oleh supervisor.

Frekuensi monitoring menunjukan sebagian besar program monitoring yang dilakukan Pengawas, Kemenag Kabupaten/ Kota, Kemenag Kanwil, Kemenag Pusat dan Dinas Pendidikan, dengan frekuensi monitoring umumnya antara 1 hingga 2 kali dalam setahun. Pejabat Kemenag Kabupaten/ Kota sebagai pejabat yang paling sering melakukan monitoring terhadap ponpes dalam mengevaluasi program wajar dikdas. Untuk Ula dinyatakan $72.4 \%$ Kemenag Kabupaten / Kota dan $81.9 \%$ Wustha pernah melakukan monitoring ke ponpes

Menurut buku petunjuk teknis pelaksanaan program ini, bahwa materi yang perlu dimonitoring dari pelaksanaan wajar dikdas adalah (1). pencapaian target kurikulum, (2). pencapaian target kegiatan ponpes, (3). kehadiran guru, karyawan dan santri serta (4). ketersediaan alat peraga pendidikan dan buku teks. Program monitoring akan menjadi sangat efektif dalam menunjang keberhasilan program wajar dikdas apabila petugas supervisi yang melakukan monitoring mengevaluasi seluruh materi/bahan monitoring tersebut. Evaluasi ini berguna sebagai informasi atau bahan yang perlu diperbaiki selanjutnya.

Meskipun proporsi pernyataan ponpes yang pernah dimonitoring sangat tinggi akan tetapi materi monitoring nampaknya belum sepenuhnya lengkap. Berdasarkan informasi yang diberikan ponpes baik Ula maupun Wustha menyatakan bahwa materi monitoring yang lengkap yang mencakup keempat aspek materi yang ada dalam buku petunjuk teknis belum sepenuhnya dilakukan oleh petugas monitoring. Tercatat hanya ada $9.3 \%$ ponpes yang pernah dimonitoring mencakup ke 4 materi tersebut.

Berdasarkan ketentuan petunjuk teknis pelaksanaan wajar dikdas perlu dilaporkan, namun sampel tercatat hanya $80 \%$ Ula dan 81 Wustha yang membuat laporan pelaksanaan. Padahal laporan ini berguna untuk bahan kebijakan bagi pihak yang berwenang dalam membimbing program ini agar keberhasilan program dapat tercapai.

Terkait dengan penyesuaian pembelajaran tercatat mencapai $71 \%$ Ula dan $69 \%$ Wustha bahwa program wajar dikdas disesuaikan dengan pembelajaran ponpes. Artinya ponpes telah melakukan pembelajaran dengan kondisi yang ada baik waktu mapun tempat proses belajar mengajar.

Selain itu dalam Pelaksanaan program wajar dikdas juga terdapat kendala baik Ula maupun Wustha, diketahui ada 5 (lima) kendala utama yang dinyatakan oleh ponpes. Khusus program Ula yaitu (1). keterlambatan dana BOS, (2). keterlambatan terbitnya ijazah lulusan, (3). 71perpustakaan dan (5) Guru IPA tidak berlatar belakang pendidikan S.1. Sedangkan kendala-kendala yang ada 
dalam penyelenggaraan wajar dikdas Wustha hampir sama adalah (1). keterlambatan dana BOS, (2). keterlambatan terbitnya ijazah lulusan, (3). honor guru program wajar dikdas terlambat dibayar, (4). tidak memiliki perpustakaan dan (5) kurang terpenuhi guru umum.

Selanjutnya peran buku paket sangat menunjang guru dalam pembelajaran, namun sampel menunjukan ada 57.4\% Ula dan $68.7 \%$ Wustha menyatakan bahwa buku paket yang ada digunakan oleh guru dalam pembelajaran. Selain buku paket juga terdapat buku lain digunakan guru sebagai referensinya yaitu $16.7 \%$ Ula dan $17.6 \%$ Wustha. Artinya masih banyak guru yang belum menggunakan referensinsi lain. Sementara terkait penilaian sebagian besar dilakukan 2 dan 3 kali dalam setahun. Yang melakukan penilaian 2 kali ada 70\% Ula dan 71\% Wustha, sedangkan penilaian 3 kali sebanyak 30\% Ula dan 29\% Wustha.

Adapun kehadiran santri di kelas hanya mencapai $44 . \%$ Ula dan 52.\% Wustha yang menyatakan kehadiran santri lebih dari $76 \%$. Ini artinya santri masih kurang kesadarannya, karena itu perlu dimotivasi agar santri disiplin mengikuti pelajaran di kelas. Namun untuk kehadiran guru nampaknya lebih tinggi yang selalu hadir mencapai $88 \%$ Ula dan $89 \%$ Wustha dalam proses pembelajaran. Ini menunjukan bahwa guru memiliki disiplin cukup baik.

Dengan demikian hasil analisis dimensi proses tersebut dapat digambarkan sebagai berikut:

Tabel 6 : Efektivitas Dimensi Proses

\begin{tabular}{|c|c|c|c|c|}
\hline \multirow{2}{*}{ No } & Indikator & \multirow{2}{*}{$\begin{array}{c}\text { Kriteria } \\
\text { Efektif }\end{array}$} & \multicolumn{2}{|c|}{ Efektifitas \% } \\
\cline { 4 - 5 } & & Ula & Wustha \\
\hline \multirow{2}{*}{1} & $\begin{array}{l}\text { Adanya supervisi dalam } \\
\text { pembelajaran wajar dikdas }\end{array}$ & $Y a$ & $96.5 \%$ & $95,1 \%$ \\
\hline
\end{tabular}

\begin{tabular}{|c|l|c|c|c|}
\hline 2 & $\begin{array}{l}\text { Adanya monitoring } \\
\text { penyelenggaraan wajar } \\
\text { dikdas }\end{array}$ & Ya & $94,9 \%$ & $92,9 \%$ \\
\hline 3 & $\begin{array}{l}\text { Kelengkapan materi } \\
\text { monitoring }\end{array}$ & $\begin{array}{c}\text { Lengkap 4 } \\
\text { Materi }\end{array}$ & $9.3 \%$ & $9,3 \%$ \\
\hline 4 & $\begin{array}{l}\text { Laporan penyelenggara } \\
\text { program }\end{array}$ & Selalu & $80.4 \%$ & $81,3 \%$ \\
\hline 5 & $\begin{array}{l}\text { Penyesuaian pembelajaran } \\
\text { wajar dikdas dengan } \\
\text { pembelajaran ponpes }\end{array}$ & $\begin{array}{l}\text { Desesuaikan } \\
\text { seluruhnya }\end{array}$ & $71.2 \%$ & $62,4 \%$ \\
\hline 6 & $\begin{array}{l}\text { Persentase kegiatan } \\
\text { penilaian dalam satu tahun }\end{array}$ & 3 kali & $29.7 \%$ & $29.1 \%$ \\
\hline 7 & $\begin{array}{l}\text { Persentase kehadiran santri } \\
\text { di kelas }\end{array}$ & $>75 \%$ & $44.4 \%$ & $52,12 \%$ \\
\hline 8 & $\begin{array}{l}\text { Persentase kehadiran } \\
\text { guru dalam kegiatan } \\
\text { pembelajaran }\end{array}$ & Selalu & $87.3 \%$ & $75,9 \%$ \\
\hline & \multicolumn{2}{|l|}{ Keterpenuhan Dimensi Proses } & $64 . \%$ & $62,3 \%$ \\
\hline
\end{tabular}

Secara keseluruhan dilihat dari dimensi proses penyelenggaraan program wajar dikdas beradap pada tingkat "cukup terpenuhi" dengan persentase $64.8 \%$ Ula dan 62.3\% Wustha. Kontribusi terbesar adanya (1) program monitoring dan (2) adanya supervisi (pengasuh ponpes, penanggng jawab program, pengawas dan pejabat Kementerian Agama/ Dinas Pendidikan). Namun meskipun demikian masih ada hal yang masih kurang yaitu materi monitoring, karena itu perlu diperhatikan kembali, dimana efektifitas materi monitoring masih rendah (9.3\%) yang menyatakan bahwa keempat materi monitoring pernah dilakukan secara bersamaan oleh supervisor atau petugas monitoring. Hal lain yang perlu diperhatikan untuk menunjang keberhasilan program wajar dikdas adalah (1). penilaian terhadap santri baik dari sisi ulangan harian/mingguan, ujian ponpes, ujian semester atau ujian nasional, serta (2). Kehadiran santri.

\section{Aspek Produk}

Produk adalah hal-hal yang berkaitan dengan keberhasilan atau capaian 
tujuan yang menggambarkan kepuasan penyelenggaraan wajar dikdas yang dilakukan ponpes dilihat dari keinginan melanjutkan program, dimana semakin tinggi nilai manfaat yang dirasakan maka keinginan kuat dari penyelenggara agar program ini tetap berjalan di tahun berikutnya. Selain itu juga ditunjukan adanya peningkatan nilai ujian dan jumlah santri serta serapan pendidikan.

Berdasarkan data sampel, terlihat bahwa minat ponpes untuk melanjutkan program ini sangat tinggi. Tercatat Ula menyatakan 97.5\% ingin tetap melanjutkan program wajar dikdas dan Wustha mencapai 99.4\%. Ini artinya wajar dikdas masih sangat efektif, karena masih banyak yang membutuhkan. Sedangkan terkait nilai mata pelajaran menunjukan bahwa nilai Bahasa Indonesia terjadi peningkatan, meskipun peningkatannya tidak terlalu signifikan, namun mengindikasikan bahwa nilai ujian nasional santri cukup baik, karena dari tahun 2013 ke tahun 2014 terjadi peningkatan, meskipun kenaikannya hanya 0,14 demikian juga nilai ujian Matematika juga menunjukan trand yang sama terjadi peningkatan, dimana nilai ujian tahun 2014 lebih tinggi dibandingkan dengan nilai tahun sebelumnya baik Ula maupun Wustha. Ini mengindikasikan bahwa santri cukup serius dalam pembelajaran mata pelajaran umum.

Selanjutnya dari sisi serapan pendidikan baik Ula maupun Wustha menunjukan cukup menggembirakan, dari jumlah santri yang lulus santri yang melanjutkan ke jenjang lebih tinggi tahun 2014 sebanyak $41 \%$, tahun 2013 sebanyak $16 \%$ dan tahun 2012 sebanyak $40 \%$.
Serapan pendidikan tahun 2012 menunjukan bahwa mobilitas pendidikan santri cukup beragam. Santri yang melanjutkan ke jenjang lebih tinggi yang paling banyak adalah melanjutkan ke tingkat Wustha terlihat ada 64\%, diikuti ke Mts $24 \%$, SMP $10 \%$ dan ke lain-lain $2 \%$. Ini menunjukan bahwa santri lulusan wajar dikdas lebih berminat ke Wustha ketimbang lainnya, yang berarti perlu perhatian pihak Kemenag pada penyelenggaraan wajar dikdas Wustha, agar lebih baik.

Serapan pendidikan 2013 terjadi penurunan khusus santri yang melanjutkan ke Wustha hanya 62\% dibanding 2012 mencapai 64\%. Sementara santri yang melanjutkan ke MTs meningkat $1 \%$ dibanding tahun 2012. Sedangkan santri yang melanjutkan ke SMP persentasenya masih sama yaitu $10 \%$.

Adapun lulusan program wajar dikdas Ula serlihat sebarannya cukup beragam yaitu ke Wustha 58\%, MTs 26\%, SMP $14 \%$ dan lain-lain $2 \%$. Ini menunjukan bahwa wajar dikdas masih cukup dibutuhkan masyarakat khususnya santri, mengingat santri mukim di ponpes berasal dari daerah. Sedangkan persentase santri Wustha yang melanjutkan dari 62 sampel tercatat santri yag melanjutkan ke jenjang yang lebih tinggi tahun 2014 sebanyak 60\%, tahun 2013 sebanyak 64\% dan tahun 2012 sebanyak 63\%. Ini menunjukan cukup menggembirakan, dimana serapan pendidikan cukup tinggi. Santri yang melanjutkan ke tingkat Ulya tahun 2012 lebih tinggi dari yang lainnya. Tercatat santri yang melanjutkan ke Ulya 42\%, ke MA 32\%, ke SMA 0\% dan lain-lain 11\%. Serapan pendidikan tahun 2013 (Wustha) tercatat santri yang melanjutkan ke Ulya dan MA tertinggi yakni 35\%, sementara yang 
melanjutkan ke SMA dan lain-lain trendnya sama yaitu $15 \%$. Pilihan pendidikan santri lulusan Wustha cukup beragam. Namun serapan pendidikan tahun 2014 (Wustha) terlihat pluktuatif ada yang menurun dan ada yang naik. Santri yang melanjutkan ke Ulya dan ke SMA naik $1 \%$ dibanding tahun 2013, sementara santri yang melanjutkan ke MA menurun $2 \%$ dan yang memilih lain-lain bertahan pada $15 \%$.

Secara keseluruhan dilihat dari sisi nilai rerata sampel ponpes baik Ula maupun Wustha mengindikasikan bahwa program wajar dikdas cukup berhasil. Nilai ujian bahasa Indonesia, Matematika dan IPA diatas 7. Dari data sampel tersebut terlihat ada peningkatan nilai ujian dari tahun 2013 ke 2014. Demikian juga dilihat dari sisi minat ponpes sangat tinggi ingin melanjutkan program.

\section{PENUTUP}

Program penyelenggaraan wajar dikdas Ula dan Wustha dilihat dari empat dimensi yaitu konteks, input, proses dan produks secara keseluruhan berada pada tingkat terpenuhi. Pada aspek konteks berada pada tingkat "terpenuhi" dengan persentase 80.4\% Ula dan 84,6\% Wustha, yang masih perlu ditingkatkan adalah kemandirian membuat panduan untuk pelaksanaan wajar dikdas internal Ponpes, dimana persentasenya hanya mencapai $64 \%$ Ula dan 53\% Wustha.

Pada aspek input secara keseluruhan berada pada tingkat "cukup terpenuhi" dengan capaian Ula 61,3\% dan Wustha $61,9 \%$. Indikator yang berhasil ditunjukan pada kepemilikan jadwal pelajaran serta mata pelajaran yang diajarkan sudah sesuai dengan program wajar dikdas. Namun beberapa hal yang diidentifikasi sebagai indikator masih perlu ditingkatkan dari dimensi input adalah latar belakang pendidikan guru, kurikulum mata pelajaran umum yang digunakan, mata pelajaran umum yang wajib diajarkan, ketersediaan buku paket guru dan santri, kepemilikan perpustakaan, kepemilikan buku SKL, RPP dan silabus.

Aspek Proses berada pada tingkat "cukup tepenuhi" untuk tingkat Ula dengan persentase 64,8\% Ula. Namun Wustha berada pada kategori "Kurang terpenuhi" hanya mencapai 62,3\%. Dari indikator yang diukur terlihat adanya supervisi, monitoring, laporan serta penyesuaian program wajar dikdas dengan program di ponpes. Sedangkan hal yang menjadi catatan yang paling rendah perlu diperhatikan yaitu materi monitoring masih kurang lengkap menyangkut 4 aspek materi, kehadiran santri dan penilaian hasil belajar santri

Aspek produk secara keseluruhan cukup berhasil walaupun minim kenaikannya rerata nilai bahasa Indonesia, matematika dan IPA meningkat pada tahun ajaran 2014 dibanding tahun ajaran sebelumnya. Demikian juga serapan pendidikan, dimana santri lulusan Ula dan Wustha $60 \%$ ke atas melanjutkan pendidikan ke jenjang lebih tinggi. Selain itu yang menyatakan kepuasan bahwa program wajar dikdas perlu dilanjutkan ada $97.5 \%$ Ula dan $99.4 \%$ Wustha.

Selain pengukuran keempat dimensi di atas hal lain yang menjadi pekerjaan rumah untuk terus diperbaiki dalam menunjang suksesnya program wajar dikdas yaitu teridentifikasinya kendala 
yang dirasakan oleh ponpes beberapa kendala yaitu: keterlambatan dana BOS, keterlambatan terbitnya ijazah, honor guru program terlambat dibayar, tidak memiliki perpustakaan dan santri banyak yang tidak mukim di ponpes serta masih seringnya santri yang tidak masuk.

Untuk meningkatkan efektifitas pogram penyelenggaraan wajar dikdas perlu direkomendasikan sebagai berikut: 1) Direktorat Pendidikan Diniyah dan ponpes hendaknyamelakukan pembinaanterahadap penyelenggara wajar dikdas agar terampil dan profesional dalam bidang akadminis dan manajement penyelenggaraan wajar dikdas, 2) Direktorat Pendidikan Diniyah dan Ponpes bersama Balitbang perlu mengevaluasi kembali sistem supervisi dan monitoring penyelenggaraan wajar dikdas; 3) Direktorat pendidikan Diniyah dan Ponpes perlu melakukan pendampingan terhadap ponpes penyelenggara wajar dikdas untuk memberikan pengetahuan terkait pengelolaan wajar dikdas secara efektif dan efisien; 4) Direktorat Pendidikan Diniyah dan Ponpes perlu menerapkan system evaluasi dan pelaporan wajar dikdas ke depan berbasis database online; 5) Kementerian Agama dan Kemendikbud hendaknya meningkatkan kerjasama intensif untuk membuat regulasi program wajib belajar pendidikan dasar terkait pemenuhan kebutuhan guru, peningkatan kualifikasi dan kompetensi guru, pembinaan guru dan kesejahteraan guru; 6) Kementerian Agama perlu melakukan sosialisasi secara luas kepada lembaga-lembaga pendidikan formal dan masyarakat bahwa ijazah lulusan wajar dikdas mendapat pengakuan yang sama seperti pendidikan formal yang sederajat lainnya agar tidak ada perlakuan yang berbeda di masyarakat.

\section{UCAPAN TERIMA KASIH}

Syukur alhamdulillah tulisan ini dapat diselesaikan berkat bantuan dari berbagai pihak. Oleh karena itu, saya atas nama penulis menyampaikan terima kasih dan penghargaan yang setinggi-tingginya kepada berbagai pihak: Pertama, para peneliti Puslitbang Pendidikan Agama dan Keagamaan, Kedua, kepada Dr.Amril Muhammad, Dr.Asep Supena, M.Pd selaku narasumber yang telah membantu memberikan saran dan masukan baik substansi maupun teknis penulisan. Ketiga, Dr. Sastra Juanda (Kasubdit Penyetaraan Kemenag) yang telah memberikan data dan informasi terkait penyelenggaraan wajar dikdas, dan khususnya kepada para Kasi Kementerian Agama Kabupaten/Kota serta nara sumber lapangan (Pimpinan pondok pesantren di DKI Jakarta, Jawa Tengah, Jawa Timur dan Yogyakarta) yang telah bersedia memberikan informasi dan mengisi kuesioner penelitian ini, sehingga penelitian ini dapat dilaksanakan dan diselesaikan sesuai waktu yang ditetapkan. Semoga amal baik bapak/ibu/Saudara dijadikan amal saleh oleh Allah Swt dan mendapat pahala yang berlipat ganda. Amiin. 


\section{DAFTAR PUSTAKA}

Djaali, Pudji Mulyono, dan Ramly. (2004): Pengukuran Dalam Bidang Pendidikan, Jakarta, PPs. UNJ

Saputra, Dedi. (2012): Jurnal Penelitian Pascasarjana Undiksha, Vol 3, No 2 (2012)http://pasca.undiksha.ac.id/ejournal/index.php/jurnal_ap/article/ view/394 tanggal, 5 Maret 2015

Direktorat Jenderal Kelembagaan Agama Islam, Tahun (2001), Panduan Teknis Penyelenggaaraan Program Wjar Dikdas pada Ponpes Salaafiyah,

Direktorat Jederal Kelembagaan Agama Islam, Panduan Teknis Penyelenggaaraan pada Ponpes Salaafiyah, Tahun 2001

Direktorat Jendral Pendidikan Islam, tahun 2013, Statisti Pendidikan Islam, Kemenag RI. Th 2012/2013 Direktorat Pendidikan Diniyah dan Ponpes, Dokumen Data

Direktorat Pendidikan Diniyah dan Ponpes. (2014): Dokumen Data Peasantren Penyelenggara Wajar Dikdas 2014

Intruksi Presiden Nomor 5 tahun 2006 tentang Gerakan Nasional Percepatan Penuntasan Wajib Belajar Pendidikan Dasar Sembilan tahun dan Pemberantasan Buta Aksar
Rutman, Leonard. (1984): Evaluation Research Methodology, New Delhi: Sege Publication India PVT. Ltd

Norman E. Grounlund and Robert L. Linn, (1990), Measurment and Evaluation in Teaching. New York, Mac Milan Publishing Company.

Popham, W.James. (1981): ModernEducational Evaluation, New Jersey, Prenctice Hall Inc.

Peraturan Menteri Pendidikan Nasional Republik Indonesia, No 41 tahun 2007 tentang standar Proses Satuan Pendidikan Dasar dan Menengah.

Handayani, Titik. (2008): potensi dan kendala Sembilan tahun di ponpes, Jurnal Edukasi Puslitbang Penda Vol. 6 Nomor 3.

Khozin, Wahid. (2005): PPS dan penuntasan wajib belajar. dalamJurnal Edukaasi Vo; 3 Nomor IV, Puslitbang Pendidikan Agama dan Keagaamaan.

Rutman, Leonard. (1984): Evaluation Research Methodology, New Delhi, Sege Publication India PVT. Ltd, 2 ed

Popham, W. James (1981): Modern Educational Evaluation, New Jersey, Prenctice Hall Inc. 